\title{
GAS-NEUTRALIZING AND DUST-SUPPRESSING STEMMING OF BOREHOLE CHARGES FOR INCREASING THE ENVIRONMENTAL SAFETY OF EXPLOSION
}

\author{
O. Tverda*, O. Kofanova, O. Kofanov, K. Tkachuk, O. Polukarov, V. Pobigaylo \\ National Technical University of Ukraine "Igor Sikorsky Kyiv Polytechnic Insti- \\ tute", Institute of Energy Saving and Energy Management, \\ 115 Borshchahivska Str., Kyiv, 03056, UKRAINE \\ *e-mail: tverdaya@ukr.net
}

The problem of environmental pollution during the explosive destruction of rocks in order to extract minerals is solved in the article. Two types of borehole charge stemming design have been developed, which, in addition to the function of locking the products of the explosion, allow completely neutralizing harmful gases. The first type is the stemming design, which includes the two-stage purification of harmful gases, formed during the explosive destruction of rocks, and is based on chemisorption of gases by quicklime or production waste and physicochemical sorption (adsorption) by zeolites. Such stemming can provide complete chemical neutralization of $\mathrm{NO}_{2}$ and $\mathrm{CO}_{2}$, as well as neutralization of $\mathrm{CO}$ by zeolites, during the explosion. The second type is stemming design, which includes chemisorption of gases by slaked lime. This type of stemming has a number of advantages over the previous one. It can not only provide complete chemical neutralization of $\mathrm{NO}_{2}, \mathrm{CO}_{2}$ and $\mathrm{CO}$, but also allows abandoning zeolites, which significantly reduces the cost of its formation to obtain the effect of "irrigation" of the dust and gas cloud, which reduces the concentration of dust in the air after the explosion to provide a higher degree of conversion. The paper determines quantitative and qualitative characteristics of the adsorbent composition of the two types of stemming depending on the type of explosive, the amount and type of harmful gases formed during explosion, and the parameters of the borehole.

Keywords: Borehole charge, environmental pollution, explosion, explosive, harmful gases, neutralization of gases, stemming. 
The mining industry is one of the main industries in many countries of the world. During the extraction of solid (strong) minerals, blasting operations are an integral part of the preparation for excavation. A large volume of gas and dust is produced during the blasting operation, especially in quarries, and then released into the atmosphere (Table 1). Commercial explosives are the major sources of pollutants. There is maximum detonation energy for destruction of the rock mass and minimum of harmful gases if the oxygen equilibrium of the explosive is zero. If the oxygen balance of the explosive deviates from zero gases caused by detonation can appear in the form of steam, carbon dioxide, nitrogen and some toxic and harmful gases, such as nitrogen monoxide, nitrogen dioxide and carbon monoxide [2].

During the interaction between oxides of nitrogen (except NO) and carbon (IV) oxide with water vapor, aerosols of nitric, nitrous and carboxylic acids are formed, the deposition of which on the soil leads to an increase of nitrates, nitrites and carbonates in it, and during entering water bodies - to acidification of water. Oxidizing hemoglobin to methemoglobin, nitrates and nitrites disrupt its transport function. Carbon (II) oxide, in turn, causes poisoning of the body due to the formation of carboxyglobin in the blood and thereby blocking the transport of oxygen. Carbon dioxide is one of the greenhouse gases and is involved in global warming [3].

It should be noted that the simultaneous formation of harmful gases and dust during the explosion is accompanied by the adsorption of these gases by the developed surface of dust particles [4]. These toxic gases pollute the mining area and its adjacent environment, which can endanger humans (workers), animals, and plants. A new blasting pattern and the controlling methods for the pollutants, especially by changing the stemming materials and length, can provide a safe environment for the ecosystem [2].

It is known that the efficiency of the explosion is largely determined by the parameters of the stemming [5]. Its volume and quality determine the level of explosive energy using to destroy the rock mass, the uniformity of rock mass fragmentation, as well as the volume of the dust and gas cloud [6]. The main purpose of stemming is to lock the products of the explosion reliably for a time until the secondary reactions of detonation decomposition of the explosive are carried out, and the energy of the expanding gases is converted into mechanical work of destruction and moving of the massif. Along with regulating the intensity of rock crushing, stemming should prevent premature gas ejection from the borehole, which is accompanied by incomplete decomposition of explosion products and leads to an increase in toxic components in the gas mixture, destruction of the wellhead with uncontrolled scattering of individual pieces of rock [5].

As a result of numerous studies, it has been established that the behaviour and efficiency of stemming during mass explosion depend on the physical and mechanical properties of the stemming material, the size of its particles, compression, friction with the walls of the charging cavity etc. [7].

A significant number of scientific papers are devoted to the choice of rational design and material of stemming [7]-[26]. However, mainly the stemming designs, which create the maximum resistance to the ejec- 
tion of explosive products, are presented in these papers. At the same time, not enough attention is paid to the ejection of detona- tion products into the atmosphere through the stemming material [8].

Table 1. Estimated Emissions of Harmful Gases from Blasting Operations for the Extraction of the Most Common Minerals in the World

\begin{tabular}{|c|c|c|c|c|c|c|}
\hline \multirow[t]{2}{*}{ Mineral } & \multicolumn{2}{|c|}{$\begin{array}{l}2019 \text { World production (according to } \\
\text { Mineral Commodity Summaries } 2020 \text { - } \\
\text { USGS, University of Waterloo) }\end{array}$} & \multirow{2}{*}{$\begin{array}{c}\text { Specific } \\
\text { consumption } \\
\text { of explosive, } \\
\mathrm{kg} / \mathrm{m}^{3}[1]\end{array}$} & \multirow{2}{*}{$\begin{array}{l}\text { Volumes of } \\
\text { explosives use/ } \\
\text { average value, } \\
\text { millions of kilo- } \\
\text { grams }\end{array}$} & \multirow{2}{*}{\multicolumn{2}{|c|}{$\begin{array}{l}\text { The amount of harmful } \\
\text { gases (for example, an } \\
\text { explosive - Granemit } \\
\text { I-30), millions of liters }\end{array}$}} \\
\hline & $\begin{array}{l}\text { millions of } \\
\text { metric tons }\end{array}$ & millions of cubic meters & & & & \\
\hline \multirow{3}{*}{ Gravel } & \multirow{3}{*}{50000} & \multirow{3}{*}{18519} & \multirow{15}{*}{$\frac{t}{i}$} & \multirow{3}{*}{$\frac{12963-25927}{19445}$} & $\mathrm{CO}_{2}$ & 1516710 \\
\hline & & & & & $\mathrm{CO}$ & 525015 \\
\hline & & & & & $\mathrm{NO}_{2}$ & 4083 \\
\hline \multirow{3}{*}{ Iron Ore } & \multirow{3}{*}{2500} & \multirow{3}{*}{481} & & \multirow{3}{*}{$\frac{337-673}{505}$} & $\mathrm{CO}_{2}$ & 39390 \\
\hline & & & & & $\mathrm{CO}$ & 13635 \\
\hline & & & & & $\mathrm{NO}_{2}$ & 106 \\
\hline \multirow{3}{*}{ Bauxite } & \multirow{3}{*}{500} & \multirow{3}{*}{200} & & \multirow{3}{*}{$\frac{140-280}{210}$} & $\mathrm{CO}_{2}$ & 16380 \\
\hline & & & & & $\mathrm{CO}$ & 5670 \\
\hline & & & & & $\mathrm{NO}_{2}$ & 44 \\
\hline \multirow{3}{*}{ Lime } & \multirow{3}{*}{430} & \multirow{3}{*}{154} & & \multirow{3}{*}{$\frac{108-216}{162}$} & $\mathrm{CO}_{2}$ & 12636 \\
\hline & & & & & $\mathrm{CO}$ & 4374 \\
\hline & & & & & $\mathrm{NO}_{2}$ & 34 \\
\hline \multirow{3}{*}{ Gypsum } & \multirow{3}{*}{140} & \multirow{3}{*}{64} & & \multirow{3}{*}{$\frac{45-90}{68}$} & $\mathrm{CO}_{2}$ & 5304 \\
\hline & & & & & $\mathrm{CO}$ & 1836 \\
\hline & & & & & $\mathrm{NO}_{2}$ & 14 \\
\hline
\end{tabular}

In particular, in [9] it has been established that proper application of air-decking and stemming plugs may enhance explosive energy utilization to a good extent. The developed stemming plug has acronym SPARSH and can effectively be used with air-decking. Further, SPARSH does not restrict the type of stemming material and stemming length.

The authors of [10] propose using a shortened to 7-14 diameters of the charge stemming with an air gap under it, which allows you to qualitatively crush the upper part of the ledge and improve rock fragmentation in general. In [7], it is noted that increasing the intensity of rock crushing during explosion can be achieved as a result of application of scattered stemming, which provides not only tight locking of the detonation products in the charging cavity, but also the activation of gas-dynamic processes in the stemming material due to the creation of air gaps in it and the formation of inert rigid inserts.

The authors of [5] have set the dependence between the stemming effectiveness and the shape of its lower end, and size of the air gap between the stemming and the explosive charge. Yurchenko in [6] presents the stemming design based on the use of a rubber stopper with an anchor device. Vorobiov [8] substantiates the effectiveness of combined stemming use in borehole charges with the location in it the S-shaped line of the detonation cord.

A significant number of scientific papers are aimed at substantiating the most effective stemming material for blasting 
boreholes. In particular, study [11] aims at assessing the impact of drill cuttings use as stemming on blasting results. The screened drill cuttings having size of 3-7 $\mathrm{mm}$ have provided the improved blasting results in terms of reduced gas ejection, less dusty environment, less fly rock, better fragmentation, loose muckpile and reduced explosive consumption.

The authors [12] argue that a correct material and size (length) of stemming can theoretically be determined if the detonation wave is known. In the case that the detonation wave is not available, it is suggested to follow some basic rules. First, it is better to choose a stemming material the impedance of which is greater than that of the explosive. Second, the stemming must be long enough to allow the detonation wave to be kept in the blast hole much longer than the total detonation time after the detonation is completed.

The three new stemming plugs are designed based on literature review and onsite observations by Atta Ur Rehman. In terms of ease of operation and utilization plastic molded stemming plugs have been better than quick setting cement and air-plugs. From the economic point of view, quick setting cement has been the best one. All of the stemming plugs have reduced the volume of secondary blasting [13].

In [14], the effect of different stemming types on the results of the explosion has been researched. Stemming types have been ranged from sand to various sized limestone. Use of different particle sizes of stemming material has shown a significant decrease in stemming ejection velocity than the use of increased particle sizes.

In [15], the developed plaster stemming method is researched and compared with the usual dry drill cutting stemming method for surface blasting in quarries. Dry drill cuttings eject very easily from blast holes without offering much resistance to blast energy. The plaster stemming method has been found to be better than the drill cutting stemming method due to the increased confinement inside the borehole and better utilization of explosive energy in the rock. The main advantage of the new stemming method is the reduction in the cost of blasting.

The recording of the blasting with the high-speed camera during testing surfactants as stemming has allowed observing the behaviour of these mixtures. The "mushroom effect" during blasting has shown that the mixture is able to retain dust closer to the ground, avoiding vertical dispersion and subsequent transport due to wind. The addition of glycerin to the mixture in the laboratory has proven to improve the surfactant characteristics, so its use has been recommended [16].

The authors [17] have developed stemming, which consists of a low-density porous material and a layer of drill cuttings. The aim of low-density porous stemming use is to enhance the explosive effect and the possibility of dust suppression. After the borehole is loaded with explosive, the space above the charge is filled with foam gel in the sleeve, the top of the sleeve is filled with drill cuttings. Improved explosive effect is explained by the fact that the propagation velocity of the stress wave has a finite value, and, depending on the blockiness of the massif, amounts to $800-3000 \mathrm{~m} / \mathrm{s}$ in the rock, $330 \mathrm{~m} / \mathrm{s}$ in air, and $1500 \mathrm{~m} / \mathrm{s}$ in water, and in the low-density composition only $30-50 \mathrm{~m} / \mathrm{s}$.

However, the known designs of stemming are aimed to a greater extent at improving the efficiency of blasting. Such stemming makes it possible to partially reduce dust emissions, but does not neutralize harmful gases. Developed designs of stemming, which focus on their shape and 
size, and which do not take into account the quality of the stemming material in terms of the ability to adsorb harmful gases, are not able to reduce the man-caused load on the environment from a mass explosion. Attempts to solve this problem have been made by the authors of [18]-[26].

In [18], it has been proposed to neutralize harmful gases using slaked lime directly in the stemming above the upper end of the charge. The authors of [4] present the results of experiments to reduce the level of hazardous emissions into the atmosphere during mass explosions due to the use of aqueous stemming with an admixture of steaming solution containing calcium hydroxide $\mathrm{Ca}(\mathrm{OH})_{2}$. Due to this impurity coagulation of dust particles and partial neutralization of toxic gaseous substances are achieved. The optimal concentrations of this solution in internal, external and combined stemming are determined.

The authors of [19] have developed a method of dust and gas suppression during mass explosions using solid stemming moistened with an aqueous solution of a carbonic reagent with a concentration of $1-2$ wt. $\%$, and a protective screen in the form of a moistened layer of rocks on the surface of the block. The authors [20] propose adding to the composition of the stemming material salts of alkaline earth metal. The addition of salts of alkaline earth metal will reduce more than 3 times the yield of nitrogen (II) oxide and nitrogen (IV) oxide and more than 2 times carbon (II) oxide during the explosion. The presence of a plasticizer allows for the formation of different shapes of the stemming, which makes it possible to significantly expand the scope of its application. Katanov and Skachilov [21] have proposed filling the space above the explosive charge column with a lowdensity composition.

The authors of [22] have conducted extensive experimental research of different types of stemming. Higher quality of locking of explosion products by the combined stemming with the embedded element in comparison with the backfill stemming has been confirmed. Leschinsky has developed the design of a universal combined stemming, the spacer element of which is a concrete cone, which is installed in an explosive borehole on the backfill site where drill cuttings are placed [23]. In [24], it has been proven that during the layer formation of the combined stemming with alternating layers of drill cuttings and elements of stone material the resistance of its emission by the pressure of the explosion products increases sharply, which allows you to reduce the length of the stemming by half. Several types of stemming have been developed in [25], in particular: incomplete stemming (with a reduced mass of stemming material), step stemming (the stemming material is scattered in sections by air gaps) and closing charge.

In [26], algorithms for calculating the effect of explosive auxiliary materials on the oxygen balance of the system "explosive - auxiliary materials" are proposed. The influence of auxiliary materials on the enthalpy of the explosion process and the composition of the explosion products is shown on the example of Gramonite 79/21.

As a result of the analysis of technological and design solutions according to existing methods of stemming borehole charges the following should be noted. Stemming with an improved shape or inert gaps along the length or between the stemming and the charge is aimed at increasing the efficiency of the technological process and does not take into account modern requirements for the air of the working area and surrounding areas. In addition, its formation in borehole is quite time consuming. Liquid stemming, in addition to being expensive in terms of 
component composition, requires the manufacture of special tanks and fasteners to form it in boreholes. Stemming in the form of a closing charge is used in cases when the upper part of the ledge is composed of stronger and denser rocks in comparison with its lower part. The use of such stemming leads to crushing, sometimes removal of the lower part of the ledge and subsidence of the upper dense part without any destruction. There is a danger of an air shock wave inherent in blasting without stemming. Therefore, the development of universal stemming, which would pro- vide the necessary fractional composition of rock mass, a high level of environmental safety during explosive destruction of rocks, with low labour and financial costs, is an urgent scientific and practical task. The analysis has shown that attempts to reduce the man-made load on the environment during the explosion due to the rational choice of explosive do not provide the necessary results. The choice of explosive with higher environmental performance causes unsatisfactory results of the explosion (a significant amount of oversize, thresholds on the sole of the ledge, etc.) [27].

\section{THEORY}

Based on the possible composition of the dust and gas cloud $\left(\mathrm{CO}, \mathrm{CO}_{2}, \mathrm{NO}\right.$, $\mathrm{NO}_{2}$ ), the authors have developed a stemming design [28], which involves two-stage cleaning of harmful gases during the process of explosive destruction of rocks and is based on chemisorption of gases by quicklime and physicochemical sorption (adsorption) by zeolites.

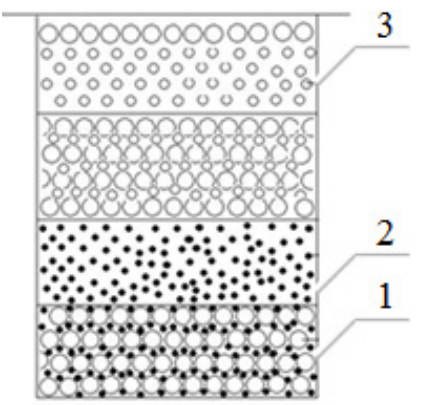

Fig. 1. The stemming design with two-stage cleaning of harmful gases: 1 - gravel; 2 - quicklime or waste containing it; 3 - zeolites or slags [28].

During the first stage, special attention is paid to the chemisorption of nitrogen (IV) oxide by quicklime, while other gases in a certain amount will be further adsorbed by zeolite (Fig. 1). It should be noted that during the first stage it is important to com- pletely chemisorb $\mathrm{NO}_{2}$. First, $\mathrm{NO}_{2}$ is the most harmful component, and, secondly, it is able to form dimers $2 \mathrm{NO}_{2} \leftrightarrow \mathrm{N}_{2} \mathrm{O}_{4}$, due to which its adsorption by zeolites can be significantly complicated.

Chemisorption of nitrogen (IV) oxide by quicklime during an explosion is described by the following reactions:

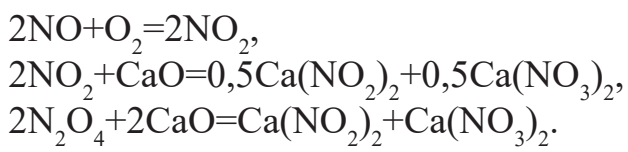

If we take into account that 50:50\% $2 \mathrm{NO}_{2} \leftrightarrow \mathrm{N}_{2} \mathrm{O}_{4}$, the chemisorption of $\mathrm{NO}_{2}$ by $1 \mathrm{~kg}$ of $\mathrm{CaO}$ is $0.6 \mathrm{~m}^{3}$. Taking into account the degree of chemisorption $(\sim 99 \%)$, the volume of chemisorbed gas decreases to $0.594 \mathrm{~m}^{3}$.

As for $\mathrm{CO}$, this oxide is non-salt-forming, and therefore does not react directly with $\mathrm{CaO}$. However, during an explosion and in the presence of oxygen in the air, such processes are possible:

$$
\begin{aligned}
& 2 \mathrm{CO}+\mathrm{O}_{2}=2 \mathrm{CO}_{2}, \\
& 2 \mathrm{CO}_{2}+2 \mathrm{CaO}=2 \mathrm{CaCO}_{3} .
\end{aligned}
$$


For a precise calculation, the degree of conversion is taken into account by the reaction $2 \mathrm{CO}+\mathrm{O}_{2}=2 \mathrm{CO}_{2}$. It is assumed that this reaction takes place with $\eta=0.7$ (70 $\%$, as there is a possibility of lack of oxygen. Taking into account the degree of conversion by this reaction of $70 \%, 0.7 \mathrm{dm}^{3}$ is obtained, i.e., 0.7 liters of $\mathrm{CO}_{2}$ are formed from each liter of $\mathrm{CO}$.

Taking into account the reaction of quicklime with carbon (IV) oxide:

$$
\mathrm{CaO}+\mathrm{CO}_{2}=\mathrm{CaCO}_{3} \text {, }
$$

it is calculated that $1 \mathrm{~kg}$ of $\mathrm{CaO}$ chemisorbs $400 \mathrm{dm}^{3}$ of $\mathrm{CO}_{2}$. Taking into account the degree of conversion $\eta=0.99,1 \mathrm{~kg}$ of $\mathrm{CaO}$ theoretically chemisorbs $396 \mathrm{dm}^{3}$ of $\mathrm{CO}_{2}$.

Conclusions on the degrees of conversion of nitrogen (IV) oxide and carbon (IV) oxide by quicklime are based on the values of the activation energy $\mathrm{E}_{\mathrm{A}}$ of these processes. Since the values of $\mathrm{E}_{\mathrm{A}}$ range from $40 \mathrm{~kJ} / \mathrm{mol}$ to $100 \mathrm{~kJ} / \mathrm{mol}$, most of the collisions of the reacting particles lead to a chemical interaction, and, consequently, the reaction rate is very high. In addition, due to the explosion, the dispersion of the system increases sharply, and, consequently, the area of the interfacial surface increases, which, in turn, increases the rate of the interaction of the reacting particles.

Based on our research to increase the environmental safety level of the explosive destruction of rocks, the developed stemming design has been improved. The new stemming design is based on chemisorption of gases by calcium hydroxide (Fig. 2). Slaked lime as a suspension of dense consistency is proposed to pour directly into the borehole after the formation of the charge.
To prevent the penetration of the suspension into the explosive, in the case of its placement without a sleeve, it is proposed to form a special "filling" in each borehole, on which the pre-prepared suspension of calcium hydroxide will be poured. The formation of the "filling" does not require significant labour and financial costs, as it is based on the addition to the suspension of slaked lime $\mathrm{Ca}(\mathrm{OH})_{2}$ methylcellulose $\mathrm{C}_{6} \mathrm{H}_{7} \mathrm{O}_{2}(\mathrm{OH})$ ${ }_{x}\left(\mathrm{OCH}_{3}\right)_{y}$ or sodium silicate $\mathrm{Na}_{2} \mathrm{SiO}_{3}$ with the formation of calcium silicate ("filling") and sodium hydroxide, which, in turn, will actively neutralize nitrogen oxides and carbon dioxide:

$\mathrm{Na}_{2} \mathrm{SiO}_{3}+\mathrm{Ca}(\mathrm{OH})_{2}=\mathrm{CaSiO}_{3}+2 \mathrm{NaOH}$, $2 \mathrm{NO}_{2}+2 \mathrm{NaOH}=\mathrm{NaNO}_{2}+\mathrm{NaNO}_{3}+\mathrm{H}_{2} \mathrm{O}$, $2 \mathrm{NaOH}+\mathrm{CO}_{2}=\mathrm{Na}_{2} \mathrm{CO}_{3}+\mathrm{H}_{2} \mathrm{O}$.

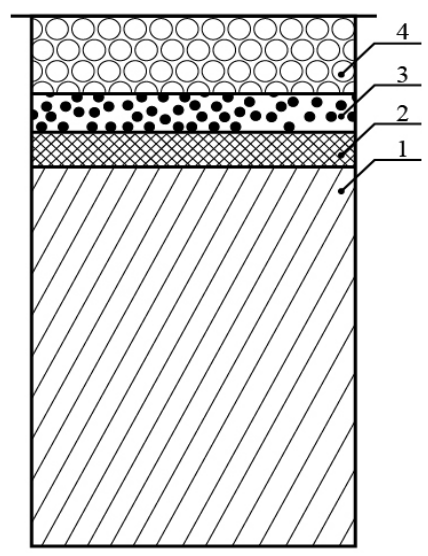

Fig. 2. The borehole charge stemming design, which includes chemisorption of

gases by slaked lime: 1 - explosive; 2 - "filling"; 3 - slaked lime suspension of dense consistency; 4 - gravel.

The next and last step in the formation of the stemming is backfilling the gravel to increase the resistance of the ejection of stemming by detonation products.

$$
\begin{aligned}
& 2 \mathrm{Ca}(\mathrm{OH})_{2}+4 \mathrm{NO}_{2}=\mathrm{Ca}\left(\mathrm{NO}_{2}\right)_{2}+\mathrm{Ca}\left(\mathrm{NO}_{3}\right)_{2}+2 \mathrm{H}_{2} \mathrm{O}, \\
& 2 \mathrm{NO}+\mathrm{O}_{2}=2 \mathrm{NO}_{2}, \\
& 2 \mathrm{NO}_{2}+\mathrm{Ca}(\mathrm{OH})_{2}=1 / 2 \mathrm{Ca}\left(\mathrm{NO}_{2}\right)_{2}+1 / 2 \mathrm{Ca}\left(\mathrm{NO}_{3}\right)_{2}+\mathrm{H}_{2} \mathrm{O},
\end{aligned}
$$


$\mathrm{Ca}(\mathrm{OH})_{2}+\mathrm{CO}_{2}=\mathrm{CaCO}_{3}+\mathrm{H}_{2} \mathrm{O}$,

$2 \mathrm{CO}+\mathrm{O}_{2}=2 \mathrm{CO}_{2}$,

$2 \mathrm{CO}_{2}+2 \mathrm{Ca}(\mathrm{OH})_{2}=2 \mathrm{CaCO}_{3}+2 \mathrm{H}_{2} \mathrm{O}$.

The use of slaked lime suspension as a chemisorbent will allow not only neutralizing harmful gases formed during the explosion, but also providing the effect of irrigation of the dust and gas cloud, which, in turn, will reduce the concentration of dust in the air, as at a temperature above $520^{\circ} \mathrm{C}$ :

$\mathrm{Ca}(\mathrm{OH})_{2}=\mathrm{CaO}+\mathrm{H}_{2} \mathrm{O}$.

In addition, calcium hydroxide reacts with carbon monoxide at a temperature of about $400{ }^{\circ} \mathrm{C}$, which allows abandoning zeolites compared to the use of calcium oxide as a chemisorbent:

$\mathrm{Ca}(\mathrm{OH})_{2}+\mathrm{CO}=\mathrm{CaCO}_{3}+\mathrm{H}_{2}$.

\section{RESULTS AND DISCUSSION}

The results of calculating the amount of harmful gases that $1 \mathrm{~kg}$ of $\mathrm{CaO}$ and $1 \mathrm{~kg}$ of $\mathrm{Ca}(\mathrm{OH})_{2}$ can chemisorb are given in Table 2. According to [29], the amount of gases formed from $1 \mathrm{~kg}$ of explosive is $\left(\mathrm{dm}^{3} / \mathrm{kg}\right)$ : $\mathrm{NO}_{2}-0.21 ; \mathrm{CO}-27 ; \mathrm{CO}_{2}-78 ; \mathrm{N}_{2}-215$. Given that the diameter of the borehole is $250 \mathrm{~mm}$, the diameter of the charge -160 $\mathrm{mm}$, the length of the borehole $-16 \mathrm{~m}$, the length of the charge $-12 \mathrm{~m}$ and the length of the stemming $-4 \mathrm{~m}$, the amount of gases from 1 borehole will be $\left(\mathrm{dm}^{3}\right): \mathrm{NO}_{2}-60.9$; $\mathrm{CO}-7830 ; \mathrm{CO}_{2}-22620 ; \mathrm{N}_{2}-62350$.
The total mass of $\mathrm{CaO}$ required for the planned chemisorption volumes will be:

$m_{\mathrm{CaO}}=0.1+57.1+13.8=71 \mathrm{~kg}$.

Thus, $2349 \mathrm{dm}^{3}$ of CO should be adsorbed by the zeolite.

The total mass of $\mathrm{Ca}(\mathrm{OH})_{2}$ required for the planned chemisorption volumes will be:

$m_{\mathrm{Ca}(\mathrm{OH}) 2}=0.1+75.4+36.9 \approx 112 \mathrm{~kg}$.

Table 2. Volumes of Chemisorption of Gases Formed during the Explosion by One Kilogram of Quicklime and One Kilogram of Slaked Lime

\begin{tabular}{|c|c|c|c|}
\hline $\begin{array}{l}\text { Gas formed during the } \\
\text { destruction of rocks by } \\
\text { explosive }\end{array}$ & $\begin{array}{c}\text { The volume of gas } \\
\text { chemisorption by } 1 \mathrm{~kg} \text { of } \\
\mathrm{CaO}, \mathrm{dm}^{3}\end{array}$ & $\begin{array}{l}\text { The volume of gas } \\
\text { chemisorption by } 1 \mathrm{~kg} \text { of } \\
\mathrm{Ca}(\mathrm{OH})_{2}, \mathrm{dm}^{3}\end{array}$ & The degree of conversion \\
\hline $\mathrm{NO}_{2}$ & 594 & 450 & 0.99 \\
\hline $\mathrm{CO}_{2}$ & 396 & 300 & 0.99 \\
\hline $\begin{array}{l}\mathrm{CO}_{2} \text { formed by the } \\
\text { reaction } 2 \mathrm{CO}+\mathrm{O}_{2}=2 \mathrm{CO}_{2}\end{array}$ & 396 & - & 0.70 \\
\hline $\mathrm{CO}$ & - & 212 & 0.7 \\
\hline
\end{tabular}

According to experimental literature data [30] for NO (and the adsorption of CO is similar due to the similar size of the molecules), $1 \mathrm{~g}$ of zeolite (KA) adsorbs (maximum) $0.35 \mathrm{~g}$ of $\mathrm{CO}$ or $0.28 \mathrm{dm}^{3}$. Therefore,
$8389.29 \mathrm{~g}$ or $8.4 \mathrm{~kg}$ of zeolite are required to adsorb $2349 \mathrm{dm}^{3}$ of CO.

Given that with increasing temperature physical adsorption deteriorates, the mass of zeolite, in the case of quicklime, 
it is proposed to double $(17 \mathrm{~kg})$. This takes into account not only the physicochemical adsorption processes during the explosion, but also the subsequent adsorption on zeolites, which will be in a suspended state for a long time (according to experimental data, the dust cloud in sedimentary dry weather will sediment (settle under the action of gravity) for 3-3.5 hours or more). At the same time, the degree of dispersion of the system during the explosion will cause an increase in the interfacial surface of the reacting particles and, as a consequence, an increase in the degree of conversion (adsorption) of carbon monoxide. Under these conditions, the sorption of oxygen and nitrogen in the air can be neglected due to the very small size of their molecules and, therefore, due to their insignificant adsorption on the pore surface of the zeolite.

Thus, based on the calculation of the required amount of adsorbent at each stage of purification and justification of its feasibility, the quantitative and qualitative characteristics of the adsorbent in stemming depending on the type of explosive, the amount and type of harmful gases formed during the explosion and borehole parameters have been obtained:

$m_{\mathrm{CaO}}=\frac{\pi}{4} \rho_{e x} d_{c h}^{2} l_{c h}\left[\frac{V_{\mathrm{NO}_{2}}}{594}+\frac{V_{\mathrm{CO}}}{396}+\frac{0,7 V_{\mathrm{CO}}}{396}\right]$

$m_{z}=\frac{\pi}{2} \rho_{e x} d_{c h}^{2} l_{c h} \frac{0,3 \cdot V_{C O}}{1000 \cdot n}$,

$m_{\mathrm{Ca}(\mathrm{OH})_{2}}=\frac{\pi}{4} \rho_{e x} d_{c h}^{2} l_{c h}\left[\frac{V_{\mathrm{NO}_{2}}}{450}+\frac{V_{\mathrm{CO}_{2}}}{300}+\frac{V_{\mathrm{CO}}}{212}\right]$,

where $\rho_{e x}$ - density of explosive, $\mathrm{kg} / \mathrm{m}^{3} ; d_{c h}$ - charge diameter, $\mathrm{m} ; l_{c h}$ - charge length, $\mathrm{m} ; V-$ volume of relevant harmful gas from $1 \mathrm{~kg}$ of explosive, $\mathrm{dm}^{3} / \mathrm{kg} ; n$-adsorption capacity of $1 \mathrm{~g}$ of zeolite, $\mathrm{dm}^{3}$.

If it is necessary to prepare a special "filling" (if the explosive in the borehole is placed without a sleeve and stemming is based on use of $\mathrm{Ca}(\mathrm{OH})_{2}$ ), an additional suspension of calcium hydroxide of dense consistency is required. For the given parameters of a charge design the rational length of a "filling" is $30 \mathrm{~cm}$. Taken into account that the density of calcium silicate is $2.9 \mathrm{~g} / \mathrm{cm}^{3}$, it is calculated that the required amount of slaked lime suspension to form a "filling" of the required size is $28 \mathrm{~kg}$, and sodium silicate $-46 \mathrm{~kg}$.

The results of calculations of the mass of quicklime, slaked lime and zeolites for complete neutralization of harmful gases are given in Table 3. The diameter of the borehole $-250 \mathrm{~mm}$, the length of the borehole - $16 \mathrm{~m}$, the charge diameter - 160 $\mathrm{mm}$, the length of the charge $-12 \mathrm{~m}$. The required amount of zeolite of each grade is calculated according to their absorbency in compliance with [30].

Thus, the two-stage purification of harmful gases using the stemming design, which includes chemisorption of gases by quicklime and physicochemical sorption (adsorption) by zeolites, can provide complete 
chemical neutralization of $\mathrm{NO}_{2}$ and $\mathrm{CO}_{2}$, as well as neutralization of $\mathrm{CO}$ by zeolites. The improved stemming design, which includes chemisorption of gases by slaked lime, not only provides complete chemical neutralization of $\mathrm{NO}_{2}, \mathrm{CO}_{2}$ and $\mathrm{CO}$, but also allows abandoning zeolites, which significantly reduces the cost of its formation, to obtain the effect of "irrigation" of the dust and gas cloud, which reduces the concentration of dust in the air after the explosion in order to provide a higher degree of conversion.
In addition, such stemming must be taken into account when choosing a rational type of explosive for blasting under specific mining and geological conditions. With the implementation of the proposed stemming design in combination with the resourcesaving design of the charge [31], it is possible not only to avoid or minimise the tax on pollutant emissions, but also to increase the efficiency of explosion and prevent mineral losses.

Table 3. The Required Amount of Reagent and Sorbent for Complete Neutralization of Harmful Gases during Detonating of Modern Explosives

\begin{tabular}{|c|c|c|c|c|c|c|c|c|}
\hline \multirow[t]{2}{*}{ Explosive } & \multirow{2}{*}{$\begin{array}{l}\text { Density } \\
\text { of } \\
\text { explosive, } \\
\mathrm{kg} / \mathrm{m}^{3}\end{array}$} & \multirow{2}{*}{\multicolumn{2}{|c|}{$\begin{array}{c}\text { The amount of gases } \\
\text { formed from } 1 \mathrm{~kg} \text { of } \\
\text { explosive, } \\
\mathrm{dm}^{3}\end{array}$}} & \multicolumn{2}{|c|}{$\begin{array}{l}\text { Required amount } \\
\text { of lime, } \\
\text { kg }\end{array}$} & \multicolumn{3}{|c|}{$\begin{array}{l}\text { The required amount of zeolite } \\
\text { (when stemming is based on use } \\
\text { of } \mathrm{CaO} \text { ), } \mathrm{kg}\end{array}$} \\
\hline & & & & $\mathrm{CaO}$ & $\mathrm{Ca}(\mathrm{OH})_{2}$ & $\mathrm{KA}$ & $13 \mathrm{X}$ & LiLSX \\
\hline \multirow{2}{*}{$\begin{array}{l}\text { Polimiks } \\
\text { GR4-T10 }\end{array}$} & \multirow{2}{*}{872} & $\mathrm{CO}_{2}$ & 52.64 & \multirow{2}{*}{59} & \multirow{2}{*}{119} & \multirow{2}{*}{37} & \multirow{2}{*}{34} & \multirow{2}{*}{33} \\
\hline & & $\mathrm{CO}$ & 82.66 & & & & & \\
\hline \multirow{2}{*}{$\begin{array}{l}\text { Polimiks } \\
\text { GR1/8 }\end{array}$} & \multirow{2}{*}{875} & $\mathrm{CO}_{2}$ & 64.85 & \multirow{2}{*}{42} & \multirow{2}{*}{64} & \multirow{2}{*}{8} & \multirow{2}{*}{8} & \multirow{2}{*}{7} \\
\hline & & $\mathrm{CO}$ & 18.48 & & & & & \\
\hline \multirow{2}{*}{$\begin{array}{l}\text { Kompo- } \\
\text { lait GS6 }\end{array}$} & \multirow{2}{*}{852} & $\mathrm{CO}_{2}$ & 39.45 & \multirow{2}{*}{39} & \multirow{2}{*}{76} & \multirow{2}{*}{22} & \multirow{2}{*}{20} & \multirow{2}{*}{19} \\
\hline & & $\mathrm{CO}$ & 50.02 & & & & & \\
\hline \multirow{2}{*}{$\begin{array}{l}\text { Polimiks } \\
\text { GR1/8 } \\
(74 \%)+ \\
\text { KRUK2 } \\
(26 \%)\end{array}$} & \multirow{2}{*}{1000} & $\mathrm{CO}_{2}$ & 73.14 & \multirow{2}{*}{49} & \multirow{2}{*}{71} & \multirow{2}{*}{6} & \multirow{2}{*}{5} & \multirow{2}{*}{5} \\
\hline & & $\mathrm{CO}$ & 10.7 & & & & & \\
\hline \multirow{2}{*}{$\begin{array}{l}\text { Polimiks } \\
\text { GR1/8 } \\
(85 \%)+ \\
\text { KRUK2 } \\
(15 \%) \\
\end{array}$} & \multirow{2}{*}{950} & $\mathrm{CO}_{2}$ & 69.99 & \multirow{2}{*}{46} & 68 & 7 & 6 & 6 \\
\hline & & $\mathrm{CO}$ & 13.62 & & & & & \\
\hline & & $\mathrm{CO}_{2}$ & 78 & & & & & \\
\hline $\begin{array}{l}\text { Hranemit } \\
\text { I-30 }\end{array}$ & 1200 & $\mathrm{CO}$ & 27 & 71 & 112 & 17 & 15 & 15 \\
\hline & & $\mathrm{NO}_{2}$ & 0.21 & & & & & \\
\hline & & $\mathrm{CO}_{2}$ & 89.2 & & & & & \\
\hline $\begin{array}{l}\text { Hranemit } \\
\text { I-50 }\end{array}$ & 1300 & $\mathrm{CO}$ & 38.8 & 92 & 151 & 26 & 24 & 23 \\
\hline & & $\mathrm{NO}_{2}$ & 0.12 & & & & & \\
\hline
\end{tabular}


The stemming design, which includes the two-stage purification of harmful gases formed during the explosive destruction of rocks, and is based on chemisorption of gases by quicklime or production waste that includes it and physicochemical sorption (adsorption) by zeolites, has been developed within the framework of the research. Such stemming can provide complete chemical neutralization of $\mathrm{NO}_{2}$ and $\mathrm{CO}_{2}$, as well as neutralization of $\mathrm{CO}$ by zeolites, during the explosion.

It is proposed to improve the developed stemming design by replacing quicklime with slaked lime. The improved stemming design, which includes chemisorption of gases by slaked lime, not only provides complete chemical neutralization of $\mathrm{NO}_{2}$, $\mathrm{CO}_{2}$ and $\mathrm{CO}$, but also allows abandoning zeolites, which significantly reduces the cost of its formation in order to obtain the effect of "irrigation" of the dust and gas cloud, which reduces the concentration of dust in the air after the explosion to provide a higher degree of conversion.

For a borehole with a diameter of 250 $\mathrm{mm}$ and a length of $16 \mathrm{~m}$, in which the charge of Hranemit I-30 with a diameter of $160 \mathrm{~mm}$ and a length of $12 \mathrm{~m}$ is formed, the total mass of $\mathrm{CaO}$ required to chemisorb nitrogen (IV) oxide and carbon (IV) oxide is $71 \mathrm{~kg}$, mass of zeolite KA, which is required for complete adsorption of carbon (II) oxide, is $17 \mathrm{~kg}$. Under the same conditions, the required amount of $\mathrm{Ca}(\mathrm{OH})_{2}$ suspension for complete neutralization of all these gases is $112 \mathrm{~kg}$.

As a result, the environmental conceptual framework of explosion by using the gas-neutralizing and dust-suppressing stemming of borehole charges has been developed. The study has identified quantitative and qualitative characteristics of the adsorbent composition of the two types of stemming depending on the type of explosive, the amount and type of harmful gases formed during explosion, and the parameters of the borehole.

\section{REFERENCES}

1. Tverda, O., \& Vorobiov, V. (2011). Specific Consumption of Explosives at Destroying the Rocks with Different Properties. Herald of the National Technical University of Ukraine «Kyiv Polytechnic Institute», Series of «Mining», 20, 52-58.

2. Abdollahisharif, J., Bakhtavar, E., \& Nourizadeh, H. (2016). Monitoring and Assessment of Pollutants Resulting from Bench-Blasting Operations. Journal of Mining \& Environment, 7 (1), 109-118. DOI: 10.22044/jme.2016.502

3. Perelot, T., Kriuchkov, A., \& Kravets, V. (2010). Justification of the Method of Gas Suppression and Neutralization of Toxic Gases during Mass Explosions in Quarries.
Herald of the National Technical University of Ukraine «Kyiv Polytechnic Institute», Series of «Mining», 19, 178-181.

4. Berezhetskyi, A., \& Vovk, O. (2004). The Use of Steaming Solutions to Reduce Dust and Gas Emissions in Mass Explosions. Herald of the National Technical University of Ukraine "Kyiv Polytechnic Institute», Series of «Mining», 11, 72-78.

5. Kravets, V., Tkachuk, K., \& Han, A. (2009). Increasing the Safety and Efficacy of Blasting Operations Using Special Designs Borehole Charges. Herald of the National Technical University of Ukraine «Kyiv Polytechnic Institute», Series of «Mining», 18, 53-57. 
6. Yurchenko, A. (2010). Reducing Emissions from Mass Explosions in Quarries by Using a Rubber Plug with an Anchor Device as a Stemming of Downhole Charges. Collection of Research Papers of the National Mining University, 35 (2), 111-117.

7. Komir, V., Blinkov, V., Romashko, A., \& Sokurenko, V. (2007). Impact of Stemming Design on the Crushing Intensity of Rock Models. KSPU Bulletin, 42 (1), 90-92.

8. Vorobiov, V. (2000). The Effectiveness of the Use of Rational Design Taps Hole Charges. Herald of the National Technical University of Ukraine "Kyiv Polytechnic Institute», Series of «Mining», 2, 51-53.

9. Saharan, M., Sazid, M., \& Singh, T. (2017). Explosive Energy Utilization Enhancement with Air-Decking and Stemming Plug, 'SPARSH'. Procedia Engineering, 191, 1211 - 1217. doi: 10.1016/j.proeng.2017.05.297

10. Shevkun, E., \& Leschinsky, A. (2006). Downhole Charges with Shortened Stemming. Mining Informational and Analytical Bulletin, 4, 139-146.

11. Choudhary, B., \& Arora, R. (2017). Screened Drill Cuttings in Blasthole for Tamping of Stemming to Reduce Generation of Fly Rock. Journal of Mines, Metals and Fuels, 65 (1), 19-23.

12. Zhang, Z. (2016). Rock fracture and blasting: Theory and applications. Butterworth-Heinenmann Elsevier. doi: 10.13140/RG.2.1.1498.2481

13. Rehman, A. (2016). Design and development of stemming plug to enhance blast performance. Lahore, Pakistan: University of Engineering and Technology. doi: 10.13140/RG.2.2.15991.47523

14. Armstrong, L. (1994). The quality of stemming in assessing blasting efficiency. Sydney, Australia: The University of New South Wales.

15. Cevizci, H. (2012). A Newly Developed Plaster Stemming Method for Blasting. Journal of the Southern African Institute of Mining and Metallurgy, 112 (12), 10711078.

16. Morera de la Vall González, G. (2018). Dust production in mining. Suppression measures in quarry blasting. Madrid, Spain: The Technical University of Madrid (UPM).

17. Katanov, I., Kondratyev, S., \& Sysoyev, A. (2019). Increasing Safety at Rock Preparation by Blasting in Open Pits. E3S Web of Conferences, 134. Available at https:// www.e3s-conferences.org/articles/e3sconf/ pdf/2019/60/e3sconf_sdemr18_01017.pdf

18. Vorobiov, V., Zakharov, V., Berezhetskyi, A., Yefremov, E., \& Barannyk, V. (2003). Reducing Dust And Gas Emission During Mass Explosion in Quarries. Herald of the National Technical University of Ukraine «Kyiv Polytechnic Institute», Series of «Mining», 8, 163-169.

19. Tyschuk, V. (2010). Studies of Specific Dust and Gas Emissions during Mass Explosions in Open Pits and Methods for Reducing Harmful Emissions. The collection "Up-to-Date Resource- and Energy-Saving Technologies in Mining Industry”, 1 (5), 127-132.

20. Vozgrin, R., Mironov, Yu., \& Moldovan, D. (2013). To the Question of the Properties of the Material for the Manufacture of Borehole and Drill Stemming. Problems of Geology and Subsurface Development, 11 (2), 304-305.

21. Katanov, I., \& Skachilov, P. (2015). Improving the Design of Borehole Charge with FoamGel Tamping. Bulletin of the Kuzbass State Technical University, 5, 43-46.

22. Shevkun, E., Leschinsky, A., Galimjanov, A., \& Rudnitsky, K. (2014). Production Tests of Combined Shothole Stemming. Mining Informational and Analytical Bulletin, 4, 97-107.

23. Leschinsky, A. (2014). Design Development Stemming Blast Holes. Electronic scientific journal "Scientists Notes PNU”, 5 (2), 6671. Available at http://pnu.edu.ru/media/ ejournal/articles-2014/TGU_5_57.pdf

24. Shevkun, E., Leschinsky, A., \& Galimjanov, A. (2015). Short Combined Stopper Explosive Chinks of High Locking Ability. Mining Informational and Analytical Bulletin, 4, 331-336.

25. Leschinsky, A., \& Shevkun, E. (2008). Clogging blast holes in quarries. Khabarovsk: Pacific National University. 
26. Gurin, A., Ermak, L., \& Teterya, O. (2008). Analytical Researches of Influence of Auxiliary Materials of Punches of Explosives in Wells on Change of Parameters of Chemical Reactions of Explosion and Structure of Products of Explosion. Labor and Environmental Protection at the Enterprises of the Mining and Metallurgical Complex, 10, 196-200.

27. Tverda, O., \& Vorobiov, V. (2012). Justification of the Selection Criterion of a Safe and Effective Type of Explosive during Mass Explosions in Open Pits. Collection of scientific works "Occupational Health and Safety Issues in Ukraine", 22, 56-64.

28. Tverda, O., \& Plyatsuk, L. (2018). The Design of Borehole Plug with a Two-Stage Absorbing System for Harmful Gases. The collection "Up-to-Date Resource- and Energy-Saving Technologies in Mining Industry", 1 (21), 103-115.
29. Zvyagintseva, A., \& Zavyalova, A. (2015). Analysis of the Basic Technological and Engineering Measures Aimed at Reducing Dust and Gas Emissions Mass Explosion at the Quarry Mining and Processing Plant. Heliogeophysical Research. Available at http://vestnik.geospace.ru/index.php?id=285

30. Prymyska, S., Beznosyk, Yu., Statyukha, G., \& Reshetilowski, W. (2010). Prospects for Purification of Thermal Energy Exhaust Gases on Synthetic Zeolites. Bulletin of NTU "KhPI", 10, 70-77.

31. Tverda, O., Plyatsuk, L., Repin, M., \& Tkachuk, K. (2018). Controlling the Process of Explosive Destruction of Rocks in Order to Minimize Dust Formation and Improve Quality of Rock Mass. Eastern-European Journal of Enterprise Technologies, 3 (10), 35-42. doi: 10.15587/1729-4061.2018. 133743 